\title{
Diet and drinking habits in relation to the development of alcoholic pancreatitis
}

\author{
J S WILSON, L BERNSTEIN, C MCDONALD, A TAIT, \\ D MCNEIL, AND R C PIROLA
}

From the Department of Gastroenterology, Division of Medicine, Prince Henry Hospital, Sydney, NSW, Australia, and the Department of Statistics, Macquarie University, North Ryde, NSW, Australia

SUMMARY To determine whether increased intakes of fat and protein or particular drinking habits are associated with the development of alcoholic pancreatitis, a dietary study has been conducted. Patients with clinically evident alcoholic pancreatitis were compared with individuals with clinically evident alcoholic cirrhosis with respect to dietary and drinking habits before the onset of clinical illness. There was no significant difference between the two groups regarding intake of nutrients, drinking habits or type of alcoholic beverage consumed.

Although alcoholism is common in western society (affecting $3-5 \%$ of men and $0.1 \%$ of women) ${ }^{1}$ only a small minority of alcoholic individuals develop clinical pancreatitis. Dietary factors and drinking habits have been considered as possible determinants of individual susceptibility to alcoholic pancreatitis. The study described in this paper was undertaken to determine whether patients with this disease differed from suitable controls with regard to: (a) their consumption of fat and protein, (b) the type of alcoholic beverage consumed and the pattern of its consumption prior to the onset of clinical disease.

\section{DIET AND PANCREATITIS}

Malnutrition has traditionally been considered to be an important association of alcoholic pancreatitis. Malnutrition (in the absence of alcoholism) is associated with pancreatitis in parts of Africa, India, and South-East Asia. ${ }^{2}$ In addition, Mezey et $a l^{3}$ have reported that pancreatic hyposecretion in alcoholics is caused by malnutrition and is reversed by feeding adequate diets.

On the other hand, there is experimental and clinical evidence to suggest that 'hypernutrition' may be a predisposing factor in this disease: (a) Several investigators have been able to increase lipase content of the pancreas of experimental animals by feeding high fat diets. ${ }^{4-9}$ Similarly,

Address for correspondence: Dr R C Pirola, 1st Floor Clinical Sciences Bldg. Prince Henry Hospital, Anzac Parade, Little Bay, NSW 2036. Australia.

Received for publication 30 October 1984 increasing the dietary protein content has been reported to increase pancreatic protease content ${ }^{10-14}$ and possibly also lipase activity. ${ }^{10}$ Although the mechanism of such dietary adaptation is unknown, its occurrence may predispose the pancreas to autodigestion. (b) High fat diets appear-to increase the severity of experimental pancreatitis in dogs ${ }^{15}$ and there is a report of pancreatitis developing spontaneously in dogs consuming large amounts of fat. ${ }^{16}$ In addition, Maki et $a l^{17}$ have reported that increases in dietary protein enhance the development of experimental pancreatitis in rats. (c) Several dietary surveys of patients with alcoholic pancreatitis have been carried out. Sarles' group ${ }^{1819}$ have reported that patients with this condition consume more fat and more protein than the normal population. The use of normal controls in these studies was unfortunate as they differed from the index group in more than one variable - they did not have pancreatitis and they were not alcoholic. In addition, it was not made clear whether the patients were interviewed about their dietary habits before or after the onset of clinical disease. Pitchumoni et al. ${ }^{20}$ reported that patients with alcoholic pancreatitis consumed more fat than patients with alcoholic cirrhosis. Both study groups were alcoholic and both groups had consumed enough alcohol to result in organ damage. The difference in fat intakes reported, however, may have been related to the 13 year average age difference between the two groups.

DRINKING HABITS AND ALCOHOLIC PANCREATITIS A survey of the literature reveals considerable geographic variation in patterns of alcohol consump- 
tion in association with alcoholic pancreatitis. In France $^{21} 22$ and Sweden ${ }^{23}$ patients are reported as consistent heavy drinkers with little variation in alcohol intake between one day and the next. In the United States, ${ }^{24}$ South Africa, ${ }^{25} 26$ Scotland, ${ }^{27}$ and Australia, ${ }^{28}{ }^{29}$ however, bout drinking is said to be more prominent in these patients.

The relationship of drinking bouts to attacks of pancreatitis is controversial. Phillips,${ }^{24}$ Marks and Bank, ${ }^{25}$ Boyer and Mackay, ${ }^{28}$ and Imrie ${ }^{27}$ have reported that attacks of pancreatitis often coincide with periodic drinking bouts. On the other hand, Saint, ${ }^{30}$ Mayday and Pheils, ${ }^{31}$ and Kager et $a l^{23}$ could find no association between attacks of pancreatitis and the imbibition of larger than usual quantities of alcohol.

The type of beverage consumed appears to be unimportant in relation to the development of alcoholic pancreatitis. Wine, spirits, beer, and cider have all been incriminated in reports from various countries. ${ }^{21-23} 25$ 32-34

With the exception of the reports of Sarles ${ }^{21}$ and of Kager $e t a l^{23}$ there are no published data to support the above claims. The drinking habits and the preferred alcoholic beverage of patients with alcoholic pancreatitis need to be documented and compared with those of a suitable control group before such factors can be accepted or dismissed as contributing to the development of the disease.

\section{Methods}

\section{STUDY GROUPS}

The dietary fat and protein intakes and the drinking habits of patients with clinically evident alcoholic pancreatitis were compared with those of patients with clinically evident alcoholic liver disease. This particular control group was chosen because these individuals had consumed enough alcohol to result in damage of an organ other than the pancreas.

If dietary factors contribute to the development of alcoholic pancreatitis, they may also play a role in other forms of pancreatic injury. Therefore, a study was also made of the dietary intakes of patients with gall stone pancreatitis. In this instance, the control group comprised individuals with one or more gall stones in their common bile ducts but without pancreatitis.

\section{CRITERIA FOR ENTRY}

(a) Alcoholic pancreatitis

Patients presenting with clinical evidence of alcoholic pancreatitis admitted to drinking $80 \mathrm{~g}$ or more of alcohol per day and manifested: (i) typical attacks of acute abdominal pain and tenderness, (ii) either a serum amylase greater than $1100 \mathrm{U} / \mathrm{l}$ (upper limit of normal $300 \mathrm{U} / \mathrm{l}$ ) or features of moderate or advanced chronic pancreatitis on a retrograde pancreatogram (according to the criteria of Kasugai $e t$ $a l^{35}$ ), (iii) negative radiographic studies of the gall bladder, normal serum calcium (in remission), fasting serum triglycerides less than twice the upper limit of normal and no relevant drug history.

\section{(b) Alcoholic liver disease}

Patients presenting with clinical evidence of alcoholic liver disease all admitted to drinking $80 \mathrm{~g}$ or more of alcohol per day and had alcoholic cirrhosis diagnosed by liver biopsy or (when deranged coagulation precluded a liver biopsy) by the presence of typical stigmata of chronic liver disease with ascites and/or oesophageal varices and with a normal serum iron or serum ferritin.

\section{(c) Gall stone pancreatitis}

All patients in this category possessed the following features: (i) typical attacks of acute abdominal pain and tenderness, (ii) a serum amylase greater than $1100 \mathrm{U} / \mathrm{l}$ (upper limit of normal: $300 \mathrm{U} / \mathrm{l}$ ), (iii) evidence of gall stones on biliary radiology or at laparotomy, (iv) normal serum triglycerides, (v) normal serum calcium (in remission), (vi) no relevant drug or alcohol history.

(d) Gall stones in the common bile duct without pancreatitis

All patients in this category had: (i) gall stones in the common bile duct found at the time of biliary surgery or with endoscopic retrograde cholangiography, (ii) no clinical evidence of pancreatitis, (iii) a normal serum amylase.

\section{DIETARY INTERVIEWS}

All patients were interviewed by a research dietitian who was unaware of their diagnosis. All interviews took place within two years of the onset of clinical disease. Information was recorded about the patients' dietary and drinking habits during the six month period before the onset of symptoms. In other words, an attempt was made to study patterns of fat, protein and alcohol intake in the premorbid state. Where possible, information about the patients' dietary habits was also obtained from relatives.

DATA ANALYSIS

Comparisons of dietary data between index patients and their controls were made with multiple regression analysis using the following multiple regression model:

$$
y=B_{0}+B_{1} x_{1}+B_{2} x_{2}+B_{3} z
$$


where

$\mathrm{y}$ is the response variable (lipid intake, protein intake, caloric intake, etc)

$\mathrm{B}_{0}$ is a constant

$\mathrm{B}_{1}, \mathrm{~B}_{2}, \mathrm{~B}_{3}$ are regression coefficients

$\mathrm{x}_{1}, \mathrm{x}_{2}, \mathrm{z}$ are explanatory variables with

$\mathrm{x}_{1}=$ age

$x_{2}=$ sex (in the case of males the variable $x_{2}$ is assigned the value 1 and in the case of females it is assigned the value 0 )

$z=$ group (for the index group $z=1$; for the control group $z=0)$.

This model allows the response variable to be related to the group while adjusting for sex and age, assuming the latter effect is linear. (No evidence for nonlinearity was apparent in the data).

In the case of the index group, the equation reduces to:

$$
\mathrm{y}=\mathrm{B}_{0}+\mathrm{B}_{1} \mathrm{x}_{1}+\mathrm{B}_{2} \mathrm{x}_{2}+\mathrm{B}_{3}
$$

In the case of the control group, it becomes:

$$
\mathrm{y}=\mathrm{B}_{0}+\mathrm{B}_{1} \mathrm{x}_{1}+\mathrm{B}_{2} \mathrm{x}_{2}
$$

The difference between the two groups is therefore $B_{3}$, which will have an expected value of zero if the null hypothesis is true. Estimates of $B_{3}$ were derived for the following response variables:

lipid intake (g/day)

protein intake (g/day)

alcohol free kilojoules (AFKj/day)

lipid intake as a percentage of $\mathrm{AFKj} /$ day

protein intake as a percentage of $\mathrm{AFKj} /$ day

alcohol intake (g/day).

Whether or not $\mathrm{B}_{3}$ was different from 0 was determined by Student's $t$ test, giving a $\mathrm{p}$ value in each case.

Data about drinking habits (type of alcoholic beverage; patterns of consumption) were compared using the $\chi^{2}$ test.

\section{Results}

Data concerning the size, average age and male/ female ratios for the four study groups are given in Table 1. Patients with alcoholic cirrhosis were, on average, 11 years older than patients with alcoholic pancreatitis and the group contained more women. The two groups with gall stone related disease had similar age and sex characteristics.

It is of interest that although the protocol allowed for the inclusion of patients with chronic pancreatitis, all patients were clinically regarded as having relapsing pancreatitis. All had had typical attacks of acute abdominal pain and tenderness. In addition, during an attack, all but two had a serum amylase greater than $1100 \mathrm{U} / \mathrm{l}$ (upper limit of normal
Table 1 Study groups

\begin{tabular}{llll}
\hline & Number & Age & $\begin{array}{l}\text { Male/Female } \\
\text { ratio }\end{array}$ \\
\hline Alcoholic pancreatitis & 20 & $40 \pm 9$ & $3 \cdot 8$ \\
Alcoholic cirrhosis & 33 & $51 \pm 11$ & $2 \cdot 2$ \\
Gall stone pancreatitis & 15 & $59 \pm 19$ & $0 \cdot 5$ \\
Gall stones in & & $61 \pm 18$ & $0 \cdot 4$ \\
$\quad$ common bile duct & 31 & 0 \\
\hline
\end{tabular}

* Mean \pm standard deviation.

300U/l). Of the remaining two, one had pancreatic calcification shown radiologically and the other had features of moderately advanced chronic pancreatitis on a retrograde pancreatogram (according to the criteria of Kasugai et $a l .{ }^{35}$ ) In nine of the patients with alcoholic pancreatitis, a pancreatogram was done and in four cases, this showed moderate or advanced features of chronic pancreatitis.

Table 2 compares the diet of patients with alcoholic pancreatitis with those of patients with alcoholic cirrhosis. It can be seen that both groups were well nourished consuming, on average, approximately 11000-14000 alcohol free kilojoules (2000-3000 calories) per day. Patients with alcoholic pancreatitis exhibited higher intakes of protein, fat (including saturated and monounsaturated fat) and carbohydrate. Alcohol intakes were similar between the two groups. Although the differences for saturated fat, carbohydrate and alcohol free kilojoules are all statistically significant ( $\mathrm{p}<0.05$ in each case), these differences should be adjusted for age and sex to obtain a valid comparison.

Table 3 presents the age and sex adjusted mean differences $\left(B_{3}\right.$ values) of the response variables exhibited in Table 2 . When age and sex were taken

Table 2 Dietary composition of groups with alcohol

\begin{tabular}{|c|c|c|}
\hline & $\begin{array}{l}\text { Alcoholic } \\
\text { pancreatitis }\end{array}$ & $\begin{array}{l}\text { Alcoholic } \\
\text { cirrhosis }\end{array}$ \\
\hline Protein (g/day) & $109 \pm 9^{*}$ & $88 \pm 5$ \\
\hline Protein (as per cent of AFK $\mathrm{j}^{\dagger}$ ) & $13 \pm 1$ & $14 \pm 0 \cdot 4$ \\
\hline Lipid (g/day) & $148 \pm 15$ & $115 \pm 8$ \\
\hline Lipid (as per cent of $\mathrm{AFKj}$ ) & $40 \pm 1$ & $41 \pm 2$ \\
\hline Polyunsaturated fat (g/day) & $12 \pm 2$ & $12 \pm 1$ \\
\hline Saturated fat (g/day) & $70 \pm 7$ & $52 \pm 4$ \\
\hline Monounsaturated fat (g/day) & $59 \pm 6$ & $45 \pm 3$ \\
\hline Cholesterol (mg/day) & $591 \pm 71$ & $529 \pm 46$ \\
\hline Carbohydrate (g/day) & $383 \pm 39$ & $289 \pm 25$ \\
\hline Carbohydrate (as per cent of $\mathrm{AFKj}$ ) & $46 \pm 2$ & $45 \pm 2$ \\
\hline Alcohol (g/day) & $147 \pm 17$ & $150 \pm 14$ \\
\hline $\mathrm{AFKj} /$ day & $3856 \pm 1289$ & $10651 \pm 731$ \\
\hline
\end{tabular}
related disease

* Results expressed as mean \pm SEM

$+\mathrm{AFKj}=$ alcohol free kilojoules. 
Table 3 Age and sex adjusted mean differences $\left(B_{3}\right)$ in dietary composition between groups with alcohol related disease

\begin{tabular}{|c|c|c|c|}
\hline & $B_{3}^{*}$ & tvaluet & $p$ value \\
\hline Protein (g/day) & 8 & $0 \cdot 82$ & 0.41 \\
\hline Protein (as per cent of $\mathrm{AFK} j \ddagger$ ) & $-1 \cdot 2$ & $-1 \cdot 6$ & $0 \cdot 12$ \\
\hline Lipid (g/day) & 19 & $1 \cdot 1$ & $0 \cdot 27$ \\
\hline Lipid (as per cent of AFKj) & -0.9 & $-0 \cdot 36$ & $0 \cdot 72$ \\
\hline Polyunsaturated fat (g/day) & $-0 \cdot 4$ & $-0 \cdot 15$ & 0.88 \\
\hline Saturated fat (g/day) & 11 & $1 \cdot 3$ & $0 \cdot 21$ \\
\hline Monounsaturated fat (g/day) & 10 & $1 \cdot 3$ & $0 \cdot 20$ \\
\hline Cholesterol (mg/day) & -30 & $-0 \cdot 34$ & $0 \cdot 75$ \\
\hline Carbohydrate (g/day) & 80 & $2 \cdot 0$ & $0 \cdot() 46$ \\
\hline Carbohydrate (as per cent $\mathrm{AFKj}$ ) & 2 & 0.72 & 0.47 \\
\hline Alcohol (g/day) & 12 & $0 \cdot 68$ & $0 \cdot 50$ \\
\hline AFKj/day & 1760 & $1 \cdot 2$ & $0 \cdot 23$ \\
\hline
\end{tabular}

* See section on data analysis for derivation of $\mathrm{B}_{3}$.

† Student's $t$ test. $\ddagger \mathrm{AFKj}=$ alcohol free kilojoules.

into account, it can be seen that patients with alcoholic pancreatitis consumed on average each $8 \mathrm{~g}$ more protein, $19 \mathrm{~g}$ more fat (mainly saturated and monounsaturated fat), $80 \mathrm{~g}$ more carbohydrate, approximately 1600 more alcohol free kilojoules and $12 \mathrm{~g}$ more alcohol. With 47 degrees of freedom for the $t$ tests, only the carbohydrate comparison was statistically significant $(p=0 \cdot 046)$, a result which is not remarkable when 12 comparisons are made (see O'Neil and Wetherill). ${ }^{36}$ Thus we may conclude that no differences are significant.

The dietary intakes of patients with gall stone pancreatitis are compared with those of patients with gall stones in the common bile duct in Tables 4 and 5. There was no difference in any dietary response variable studied.

The majority of patients with alcoholic pancreatitis and alcoholic cirrhosis were consistent heavy

Table 4 Dietary composition of groups with gall stone related disease

\begin{tabular}{lcc}
\hline & Gall stone & Gall stones \\
& pancreatitis & $\begin{array}{c}\text { in common } \\
\text { bile duct }\end{array}$ \\
\hline Protein (g/day) & $97 \pm 13^{*}$ & $99 \pm 11$ \\
Protein (as per cent of AFKj $\dagger$ ) & $14 \pm 1$ & $14 \pm 1$ \\
Lipid (g/day) & $145 \pm 23$ & $145 \pm 21$ \\
Lipid (as per cent of AFKj) & $43 \pm 2$ & $42 \pm 1$ \\
Polyunsaturated fat (g/day) & $24 \pm 6$ & $20 \pm 2$ \\
Saturated fat (g/day) & $61 \pm 10$ & $66 \pm 11$ \\
Monounsaturated fat (g/day) & $54 \pm 8$ & $53 \pm 8$ \\
Cholesterol (mg/day) & $557 \pm 100$ & $533 \pm 78$ \\
Carbohydrate (g/day) & $335 \pm 65$ & $317 \pm 25$ \\
Carbohydrate (as per cent of AFKj) & $44 \pm 2$ & $45 \pm 1$ \\
AFKj/day & $743 \pm 2041$ & $12495 \pm 1352$ \\
\hline
\end{tabular}

* Results expressed as mean \pm SEM.

$+\mathrm{AFKj}=$ alcohol free kilojoules.
Table 5 Age and sex adjusted mean differences $\left(B_{3}\right)$ in dietary composition between groups with gall stone related disease

\begin{tabular}{lccc}
\hline & $B_{3}{ }^{*}$ & $t$ value & p value \\
\hline Protein (g/day) & 1 & $0 \cdot 11$ & 0.91 \\
Protein (as per cent of AFKj $\ddagger$ ) & -0.1 & -0.13 & 0.90 \\
Lipid (g/day) & 13 & 0.56 & 0.58 \\
Lipid (as per cent of AFKj) & 2 & 0.94 & 0.35 \\
Polyunsaturated fat (g/day) & 4 & 0.74 & 0.46 \\
Saturated fat (g/day) & 1 & 0.072 & 0.94 \\
Monounsaturated fat (g/day) & 6 & 0.65 & 0.52 \\
Cholesterol (mg/day) & 104 & 1.2 & 0.24 \\
Carbohydrate (g/day) & 18 & 0.36 & 0.72 \\
Carbohydrate (as per cent AFKj) & -2 & -0.81 & 0.43 \\
AFKj/day & 706 & 0.4 & 0.69 \\
\hline
\end{tabular}

* See section on data analysis for derivation of $B$

† Student's $t$ test. $\ddagger \mathrm{AFKj} / \mathrm{day}=$ alcohol free kilojoules

drinkers with little variation in their alcoholic intake from one day to the next. Seven of the pancreatitis group and nine of the cirrhosis group admitted to drinking more heavily on one or two days per week but this difference was not significant (Table 6). There were no exclusive binge drinkers in either group.

The types of alcoholic beverage consumed by patients with pancreatitis and cirrhosis are compared in Table 7. The predominant alcoholic beverage in both groups was beer, a not unexpected finding in an Australian population. There was a slight tendency for those with cirrhosis to consume less beer and more wine. For the purposes of statistical analysis, a contingency table was con-

Table 6 Patterns of alcohol consumption in patients with alcoholic pancreatitis and with alcoholic cirrhosis

\begin{tabular}{lll}
\hline & $\begin{array}{l}\text { Alcoholic } \\
\text { pancreatitis }\end{array}$ & $\begin{array}{l}\text { Alcoholic } \\
\text { cirrhosis }\end{array}$ \\
\hline $\begin{array}{l}\text { Regular, daily consumption } \\
\begin{array}{l}\text { Heavier consumption on 1 or } 2 \\
\text { days per weck }\end{array}\end{array}$ & 13 & 24 \\
\hline
\end{tabular}

Raw $\chi^{2}=0 \cdot 35 ;$ with Yates correction $\chi^{2}=0.08(p=0 \cdot 78)$.

Table 7 Types of alcoholic beverage consumed by patients with alcoholic pancreatitis and with alcoholic cirrhosis

\begin{tabular}{lll}
\hline & $\begin{array}{l}\text { Alcoholic } \\
\text { pancreatitis }\end{array}$ & $\begin{array}{l}\text { Alcoholic } \\
\text { cirrhosis }\end{array}$ \\
\hline Beer & $68 \pm 9^{*}$ & $52 \pm 8$ \\
Spirits & $26 \pm 9$ & $20 \pm 6$ \\
Wine & $6 \pm 4$ & $28 \pm 6$ \\
\hline
\end{tabular}

* Results are expressed as mean \pm SEM of percentages of total alcohol consumption. 
Table 8 Types of alcoholic beverage consumed by patients with alcoholic pancreatitis and with alcoholic cirrhosis

\begin{tabular}{lll}
\hline Predominant beverage & $\begin{array}{l}\text { Alcoholic } \\
\text { pancreatitis }\end{array}$ & $\begin{array}{l}\text { Alcoholic } \\
\text { cirrhosis }\end{array}$ \\
\hline Beer & 14 & 19 \\
Spirits & 5 & 5 \\
Wine & 1 & 9 \\
\hline
\end{tabular}

$\chi^{2}=4 \cdot 22 ; p=0 \cdot 12$, not significant.

structed (Table 8) to which patients were assigned according to their predominant beverage. There was no statistically significant difference between the two groups.

\section{Discussion}

In this study, the diets and drinking habits of patients with clinically evident alcoholic pancreatitis have been compared with those of a group with clinically evident alcoholic cirrhosis. When one is interested in factors which render alcoholics susceptible to pancreatitis, the important comparison is between alcoholics with the disease and alcoholics without the disease. Alcoholics with cirrhosis were selected as controls to ensure that these individuals had consumed enough alcohol to result in clinical organ damage. Pitchumoni et $a^{20}$ also carried out a similar comparison but did not make adjustments for age and sex differences between the two groups.

An attempt has been made in this investigation to assess premorbid dietary and drinking habits in the patients studied. Patients were interviewed within two years of onset of clinical disease about their dietary and drinking habits in the six month period preceding their clinical presentation. The reports of Sarles et $a l^{18}$ and Durbec and Sarles ${ }^{19}$ do not make it clear whether premorbid dietary and alcohol consumption information was obtained. Although Pitchumoni et $a l^{20}$ attempted to obtain premorbid data, they did not indicate how long after the onset of clinical disease were the dietary interviews conducted. Obviously, the further back a patient has to remember, the more difficult it is to obtain accurate information.

After the data from this present study had been adjusted for age and sex with multiple regression analysis, there were no significant differences between the alcoholic pancreatitis group and the alcoholic cirrhosis group with respect to fat and protein consumption (see Tables 2 and 3 ). There was a trend for the pancreatitis patients to consume approximately $10 \%$ more protein and approximately $17 \%$ more fat but it is difficult to envisage how such small differences (even if statistically signifi- cant) could predispose to the development of pancreatitis. In this regard, it is interesting to note that patients with gall stone pancreatitis did not differ significantly from gall stone controls regarding intakes of fat or protein (Tables 4 and 5).

When the alcoholic pancreatitis and alcoholic cirrhosis groups were compared regarding their drinking habits, again no significant difference emerged. Patients with cirrhosis tended to drink less beer and more wine but this difference was not significant (Tables 7 and 8). Both groups were also similar regarding patterns of alcohol consumption (Table 6).

It is emphasised that failure to show a statistically significant difference does not disprove its existence. Despite the theoretical and experimental reasons for implicating increases in dietary fat and protein in the pathogenesis of alcoholic pancreatitis, however, the results from this dietary survey suggest that such factors are small and unimportant clinically. In addition, there is no significant evidence to suggest that type of alcoholic beverage or alcoholic drinking patterns are important determinants of individual susceptibility.

This work was supported in part by the National Health and Medical Research Council of Australia and the Australian Associated Brewers.

\section{References}

1 Goodwin DW. Alcoholism and heredity. A review and hypothesis. Arch Gen Psychiatry 1979; 36: 57-61.

2 Pitchumoni CS. Pancreas in primary malnutrition disorders. Am J Clin Nutr 1973; 26: 374-9.

3 Mezey E, Jow E, Slavin RE, Tobon F. Pancreatic function and intestinal absorption in chronic alcoholism. Gastroenterology 1970; 59: 657-64.

4 Bucko A, Kopec Z. Adaptation of enzymes activity of the rat pancreas to altered food intake. Nutritio et Dieta 1968; 10: 276-87.

5 Deschodt-Lanckman M, Robberecht P, Camus J, Christophe J. Short-term adaptation of pancreatic hydrolases to nutritional and physiological stimuli in adult rats. Biochimie 1971; 53: 789-6.

6 Christophe J, Camus J, Deschodt-Lanckman M et al. Factors regulating biosynthesis, intracellular transport and secretion of amylase and lipase in the rat exocrine pancreas. Horm Metab Res 1971; 3: 393-403.

7 Robberecht P, Deschodt-Lanckman M, Camus J, Bruylands J, Christophe J. Rat pancreatitic hydrolases from birth to weaning and dietary adaptation after weaning. Am J Physiol 1971; 221: 376-81. 
8 Snook JT. Dietary regulation of pancreatic enzymes in the rat with emphasis on carbohydrate. Am J Physiol 1971; 221: 1383-7.

9 Gidez I. Effect of dietary fat on pancreatic lipase levels in the rat. J Lipid Res 1973; 14: 169-77.

10 Grossman MI, Greengard H, Ivy AC. The effect of dietary composition on pancreatic enzymes. Am J Physiol 1943; 138: 676-82.

11 Reboud JP, Ben Abdeljlil A, Desnuelle P. Variations de la teneur en enzymes du pancreas de rat en fonction de la composition des regimes. Biochem Biophys Acta 1962; 58: 326-37.

12 Howard F, Yudkin J. Effect of dietary change upon the amylase and trypsin activities of the rat pancreas. $\mathrm{Br} J$ Nutr 1963; 17: 281-93.

13 Ben Abdeljlil A, Desnuelle P. Sur l'adaptation des enzymes exocrines du pancreas a la composition du regime. Biochim Biophys Acta 1964; 81: 136-49.

14 Johnson A, Hurwitz R, Kretchmer N. Adaptation of rat pancreatic amylase and chymotrypsinogen to changes in diet. J Nutr 1977; 107: 87-96.

15 Haig THB. Experimental pancreatitis intensified by a high fat diet. Surg Gynecol Obstet 1970; 131: 914-8.

16 Lindsay S, Entenman C, Chaikoff IL. Pancreatitis accompanying hepatic disease in dogs fed a high fat, low protein diet. AMA Arch Pathol 1948; 45: 635-8.

17 Maki T, Kakisaki G, Sato T et al. Effect of diet on experimental pancreatitis in rat. Tohoku J Exp Med 1967; 92: 301-9.

18 Sarles H, Sarles J-C, Camatte R et al. Observations on 205 confirmed cases of acute pancreatitis, recurring pancreatitis and chronic pancreatitis. Gut 1965; 6: 545-59.

19 Durbec JP, Sarles H. Multicenter survey of the etiology of pancreatic diseases. Relationship between the relative risk of developing chronic pancreatitis and alcohol, protein and lipid consumption. Digestion 1978; 18: $337-50$

20 Pitchumoni CS, Sonnenshein M, Candido FM, Panchacharam P, Cooperman JM. Nutrition in the pathogenesis of alcoholic pancreatitis. Am J Clin Nutr 1980; 33: $631-6$.
21 Sarles H. Alcoholism and pancreatitis. Scand J Gastroenterol 1971; 6: 193-8.

22 Gastard J, Joubaud F, Farbos T et al. Etiology and course of primary chronic pancreatitis in Western France. Digestion 1973; 9: 416-28.

23 Kager L, Lindberg S, Agren G. Alcohol consumption and acute pancreatitis in men. Scand $J$ Gastroenterol 1972; 7: suppl 15: 1-38.

24 Phillips AM. Chronic pancreatitis - pathogenesis and clinical features. Study of twenty-eight cases. Arch Intern Med 1954; 93: 337-54.

25 Marks IN, Bank S. The aetiology, clinical features and diagnosis of pancreatitis in the South Western Cape. A review of 243 cases. $S$ Afr Med J 1963; 37: 1039-53.

26 Marks IN, Bank S, Louw JH. Chronic pancreatitis in the Western Cape. Digestion 1973; 9: 447-53.

27 Imrie CW. Observations on acute pancreatitis. $\mathrm{Br} \mathrm{J}$ Surg 1974; 61: 539-44.

28 Boyer JT, Mackay IR. The aetiology, course and surgical aspects of pancreatitis. A review of 108 cases. Aust NZ J Surg 1060; 3: 150-7.

29 Bennett RC, Jepson RP. Acute pancreatitis in South Australia. Med J Aust 1966; 1: 126-9.

30 Saint EG. Acute pancreatitis. Med J Aust 1954; 2: 536-43.

31 Mayday GB, Pheils MT. Pancreatitis: a clinical review. Med J Aust 1970; 1: 1142-4.

32 Fung WP, Aw SE, Khoo OT. Chronic pancreatitis in Asian patients in Singapore. Med J Aust 1970; 1: 653-6.

33 Olsen H. Pancreatitis. A prospective clinical evaluation of 100 cases and review of the literature. Am J Dig Dis 1974; 19: 1077-90.

34 Rajasuriya K, Thenabadu PN, Munasinghe DR. Pancreatic calcification in Ceylon with special reference to its aetiology. Ceylon Med J 1970; 15: 11-24.

35 Kasugai T, Kuno N, Kizu M, Kobayashi S, Hattori K. Endoscopic pancreatocholangiography. II The pathological endoscopic pancreatocholangiogram. Gastroenterology 1972; 63: 227-34.

36 O'Neill R, Wetherill GB. The present state of multiple comparison methods (with discussion). J R Statist Soc (B) 1971; 33: 213-50. 